\title{
Did Amendments to the Ontario Highway Traffic Act in 2009-2010 Affect the Proportion of Alcohol-Related Motor Vehicle Collisions Seen at a Level I Trauma Centre over a 10-year Period?
}

\author{
Meghan Garnett, MD*; Tanya Charyk Stewart, BSc, MSc ${ }^{\dagger}$; Michael R Miller, PhD ${ }^{\ddagger \S}$; Rodrick Lim, $\mathrm{MD}^{\ddagger \S}$; \\ Kristine Van Aarsen, BSc, MSc*; Wanda Millard, MD*
}

\section{ABSTRACT}

Objectives: To determine if changes to the Ontario Highway Traffic Act (OHTA) in 2009 and 2010 had an effect on the proportion of alcohol-related motor vehicle collisions (MVCs) presenting to a trauma centre over a 10 -year period.

Methods: A retrospective review of the trauma registry at a Level I trauma centre in southwestern Ontario was undertaken. The trauma registry is a database of all trauma patients with an injury severity score (ISS) $\geq 12$ and/or who had trauma team activation. Descriptive statistics were calculated. Interrupted time series analyses with ARIMA modeling were performed on quarterly data from 2004-2013. Results: A total of 377 drivers with a detectable serum ethanol concentration (SEC) were treated at our trauma centre over the 10 -year period, representing $21 \%$ of all MVCs. The majority $(330 ; 88 \%)$ were male. The median age was 31 years, median SEC was $35.3 \mathrm{mmol} / \mathrm{L}$, and median ISS was 21 . A total of $29(7.7 \%)$ drinking drivers died from their injuries after arriving to hospital. There was no change in the proportion of drinking drivers after the 2009 amendment, but there was a significant decline in the average SEC of drinking drivers after changes to the law. There was no difference in the proportion of drinking drivers $\leq 21$ years after introduction of the 2010 amendment for young and novice drivers.

Conclusions: There was a significance decline in the average SEC of all drinking drivers after the 2009 OHTA amendment, suggesting that legislative amendments may have an impact on drinking before driving behaviour.

\section{RÉSUMÉ}

Objectif: L'étude visait à déterminer si les modifications apportées au Code de la route (CR) de l'Ontario en 2009 et en 2010 avaient eu une incidence sur la proportion d'accidents d'automobile (AA) liés à l'alcool et le nombre de blessés traités dans un centre de traumatologie sur une période de 10 ans.

Méthode: II s'agit d'un examen rétrospectif d'un registre de traumatismes, tenu dans un centre de traumatologie de niveau I, dans le sud-ouest de l'Ontario. Le registre consiste en une base de données sur tous les traumatisés qui ont un indice de gravité des blessures (IGB) $\geq 12$ ou dont l'état est suffisamment grave pour mobiliser une équipe de traumatologie. Des données descriptives ont servi à différents calculs, et des analyses de séries temporelles interrompues, fondées sur des données trimestrielles recueillies de 2004 à 2013 ont été effectuées à I'aide du modèle ARIMA.

Résultats: Au total, 377 conducteurs ayant un taux d'alcoolémie détectable (TAD) ont été traités au centre de traumatologie sur la période de 10 ans, ce qui représente $21 \%$ de tous les conducteurs blessés dans un AA. La plupart d'entre eux (330; $88 \%$ ) étaient des hommes. L'âge médian s'élevait à 31 ans; le TAD médian, à $35,3 \mathrm{mmol} / /$ et I'IGB médian, à 21 . En tout, 29 (7,7\%) conducteurs en état d'ébriété ont succombé à leurs blessures après leur arrivée à I'hôpital. La proportion de conducteurs en état d'ébriété n'a pas changé après les modifications apportées au CR en 2009, mais une diminution importante du TAD moyen a été notée chez les conducteurs en état d'ébriété. Enfin, aucune différence, par rapport aux années antérieures, n'a été relevée en ce qui concerne la proportion de conducteurs en état d'ébriété, âgés de 21 ans ou moins après I'entrée en vigueur des modifications apportées en 2010 visant les jeunes conducteurs et les apprentis conducteurs.

Conclusions: Une diminution importante du taux moyen d'alcoolémie a été enregistrée chez tous conducteurs en état d'ébriété après l'entrée en vigueur des modifications apportées au CR de I'Ontario en 2009, ce qui donne à penser que les modifications à la loi peuvent inciter les personnes restreindre leur consommation d'alcool avant de se mettre au volant.

Keywords: ethanol, driving under the influence, alcohol drinking, motor vehicles, legislation, emergency medicine

From the *Division of Emergency Medicine, †Trauma Program, Department of Surgery, and ¥Department of Paediatrics, Western University; and the §Children's Health Research Institute.

Correspondence to: Dr. Meghan Garnett, Victoria Hospital, 800 Commissioners Road East, London, ON, Canada N6A 5W9; Email: mgarnet@uwo.ca 


\section{INTRODUCTION}

Impaired driving is the leading cause of criminal death in Canada in spite of widespread public education on the dangers of drinking and driving. ${ }^{1}$ Over 700 Canadians are killed each year in a motor vehicle collision (MVC) involving an alcohol-impaired driver. In 2009, $28 \%$ of all road traffic fatalities involved alcohol. ${ }^{2}$ Impaired driving leading to death, injury, and property damage costs Canadians \$20 billion dollars annually. ${ }^{3}$

Over the last decade, the number of Canadians admitting to driving after consuming any amount of alcohol in the last 30 days has remained fairly constant at $19 \%$. Additionally, $5 \%$ of Canadians self-report having driven while over the legal limit in the past 12 months. Moreover, Canadians' level of concern regarding drinking and driving has steadily declined over the past decade. ${ }^{2}$

Since 1969 , it is a criminal offense to operate a motor vehicle with a blood alcohol concentration (BAC) greater than $0.08 \%(80 \mathrm{mg} / 100 \mathrm{~mL})$ in Canada. Some Canadian provinces have implemented legislative changes in an attempt to reduce the number of alcoholrelated collisions. Ontario introduced a 12-hour license suspension on December 17, 1981, for drivers with a $\mathrm{BAC} \geq 0.05 \%$. When British Columbia introduced immediate roadside prohibition legislation for impaired drivers in 2010, there were fewer fatal collisions, fewer injury collisions, and less propertydamage-only collisions relating to alcohol. ${ }^{4}$ Many other jurisdictions around the world have implemented legislative changes to combat drinking and driving, with mixed results. ${ }^{5-16}$

The Ontario Highway Traffic Act (OHTA) was amended on May 1, 2009, so that all drivers with a BAC of $0.05 \%-0.08 \%$ have their licenses immediately suspended at the roadside for three, seven, or 30 days for a first, second, or third offense, respectively. On August 1, 2010, all novice drivers under the graduated licensing system and fully licensed drivers aged 21 years and younger became legally obligated to maintain a blood alcohol concentration of zero at all times. We sought to determine if the amendments to the OHTA in 2009 and 2010 affected the proportion of severely injured drivers with a detectable serum ethanol concentration (SEC), and the average SEC of injured drivers in southwestern Ontario.

\section{METHODS}

We conducted a retrospective review of the trauma registry at London Health Sciences Centre (LHSC), which is the largest Level I trauma centre in southwestern Ontario, serving a geographic area of $28,000 \mathrm{~km}^{2}$ with over 1.8 million people. The trauma registry is a database of all trauma patients with an injury severity score (ISS) $\geq 12$ and/or trauma team activation (TTA).

All patients who were drivers in an MVC from January 1, 2004 to December 31, 2013 were eligible for inclusion. The trauma registry data were prospectively collected by trained data analysts and contain over 400 data elements per patient. Information extracted from the trauma registry included patient age, gender, date and time of injury, hospitals visited, ISS, TTA, type of motorized vehicle, protective devices (e.g., seatbelts), position in vehicle (e.g., driver), SEC, and outcome measures (e.g., death). The ethanol detection threshold at the LHSC laboratory is $2.0 \mathrm{mmol} / \mathrm{L}$, below which the ethanol concentration was recorded in the trauma registry as $0 \mathrm{mmol} / \mathrm{L}$. The first measured $\mathrm{SEC}$ was the one recorded in the trauma registry. We considered all drivers with a detectable SEC to be "drinking drivers." We excluded drivers of motorized vehicles primarily driven off-road, such as ATVs and snowmobiles. This study was approved by Western University's Health Sciences Research Ethics Board.

Descriptive statistics were calculated with Microsoft Excel. Baseline characteristics of drinking drivers before and after the 2009 law amendment were compared using the Pearson Chi Square and Mann-Whitney U tests. Interrupted time series analyses were conducted with SPSS v.23 (IBM Corporation, Armonk, NY, USA) using ARIMA (auto-regressive, integrated, moving average) modeling on quarterly data from January 2004 to December 2013 for the following three outcomes: (1) the proportion of drivers with a detectable SEC before and after the 2009 OHTA law; (2) the average SEC of drinking drivers before and after the 2009 OHTA law; and (3) the proportion of drivers $\leq 21$ years of age with a detectable SEC before and after the 2010 OHTA law. Notably, we were unable to identify novice (i.e., not fully licensed under the graduated licensing system) drivers older than 21 years from the trauma registry. The intervention points for the OHTA 2009 and 2010 laws were set at the first complete quarters, which were April-June 2009 and July-September 2010, respectively. 


\section{RESULTS}

\section{Descriptive statistics}

A total of 6,199 patients $\geq 16$ years were entered into the trauma registry from 2004 to 2013 , with 2,427 involved in an MVC and 1,800 patients as drivers in an MVC over the 10-year period. 249 drivers did not have an ethanol concentration recorded, leaving 1,551 for analysis. There were no differences in the proportion of patients who had no recorded ethanol concentration prior to and after the OHTA amendments.

Of the 1,800 severely injured drivers in the study period, $377(21 \%)$ had a detectable SEC (Table 1). The majority $(88 \%)$ were male. The median age was 31 years, and ranged from 14 to 81 years with an interquartile range (IQR) of 23 to 46 years. Twenty percent of drivers were $\leq 21$ years. The median ethanol concentration was $35.3 \mathrm{mmol} / \mathrm{L}$ (IQR $21.8-47.7 \mathrm{mmol} /$ $\mathrm{L}$ ), with a range of $2.0-99.3 \mathrm{mmol} / \mathrm{L}$.

Drinking drivers most commonly operated a passenger vehicle $(55 \%)$, followed by a light truck or van $(31 \%)$, or motorcycle (14\%) (Table 2). Only 44\% of drivers who had been drinking were wearing their seatbelts. In Ontario, motorcycle drivers are required by law to wear a helmet; $94 \%$ of motorcyclists complied. Over half $(53 \%)$ of the crashes occurred on the weekend (Saturday or Sunday). The injury profile by body region can be found in Table 3 . The median ISS for drivers with a detectable ethanol concentration was 21 (IQR 10-30). A total of 29 patients $(7.7 \%)$ died from their injuries after arrival at hospital.

\section{Time series analysis}

For each interrupted time series analysis, the data were best fit to the ARIMA model in terms of auto-regressive, integrated, and moving average components to account for variability and seasonal effects in the outcome. ${ }^{17}$ The models were then estimated to examine changes in the overall trajectory of each outcome (i.e., SEC) before and after the intervention (i.e., OHTA laws). Change was measured both in terms of level (i.e., immediate change at the start of the intervention) and in terms of slope (i.e., relative change with each additional time point prior to and after the intervention).

First, we examined the effects of the 2009 OHTA law. With the proportion of drinking drivers as the outcome, the data best fit an ARIMA $(2,0,0)$ model, but the results indicated no significant changes (both level and slope) before or after the 2009 law (Table 4). With the average SEC of drinking drivers as the outcome, the data best fit an ARIMA $(2,0,1)$ model, and results indicated a significant decrease in slope after the 2009 law (Table 4). In particular, with each additional quarter, there was a significant average decrease in SEC of $0.51 \mathrm{mmol} / \mathrm{L}$. Models for both of the 2009 law outcomes are depicted in Figures 1 and 2.

For the 2010 OHTA law, we restricted the sample to drivers $\leq 21$ years (Figure 3). With average SEC as the outcome, the data best fit an ARIMA $(2,0,0)$ model, but there were no significant changes in either level or slope in relation to the 2010 law (Table 4; Figure 3).

\section{DISCUSSION}

This study examined how stricter legislation under the OHTA in 2009 and 2010 affected the proportion of drivers with a detectable serum ethanol concentration presenting to a trauma centre in Ontario. The intent of stricter license suspension laws is to create a general deterrent effect, whereby people who were going to consume alcohol and drive are deterred from doing so

\begin{tabular}{|c|c|c|c|c|}
\hline Characteristic & Total & $\begin{array}{c}\text { Pre-Law } \\
\text { January } 1^{\text {st }}, 2004- \\
\text { April } 30^{\text {th }}, 2009\end{array}$ & $\begin{array}{c}\text { Post-Law } \\
\text { May } 1^{\text {st }}, 2009- \\
\text { December } 31^{\text {st }}, 2013\end{array}$ & $p$ value \\
\hline Male n (\%) & $330(87.5 \%)$ & $208(89.7 \%)$ & $122(84.1 \%)$ & $0.115^{*}$ \\
\hline Median age $\left(25^{\text {th }}, 75^{\text {th }}\right)$ & 31 years $(23,46)$ & 30 years $(23,44)$ & 33 years $(23,47.5)$ & $0.279+$ \\
\hline Drinking young drivers $\leq 21$ years $n(\%)$ & $76(20.2 \%)$ & $49(21.1 \%)$ & $27(18.6 \%)$ & $0.556^{*}$ \\
\hline Median ethanol concentration $\left(25^{\text {th }}, 75^{\text {th }}\right)$ & $\begin{array}{l}35.30 \mathrm{mmol} / \mathrm{L} \\
(21.75,47.65)\end{array}$ & $\begin{array}{l}32.15 \mathrm{mmol} / \mathrm{L} \\
(21.83,47.08)\end{array}$ & $\begin{array}{l}36.70 \mathrm{mmol} / \mathrm{L} \\
(20.80,48.00)\end{array}$ & $0.553+$ \\
\hline Median injury severity score $\left(25^{\text {th }}, 75^{\text {th }}\right)$ & $21(10,30)$ & $21(12,34)$ & $21(9,29)$ & $0.119+$ \\
\hline
\end{tabular}


by heavier penalties. ${ }^{6}$ Our study suggests that the 2009 amendment decreased the average SEC of people who consumed alcohol prior to driving by $3.28 \%$ per quarter or $13.12 \%$ with each additional year. Thus, the 2009 amendment seemed to have played a part in decreasing

\begin{tabular}{lr}
$\begin{array}{l}\text { Table 2. Crash and Protective Device Characteristics of } \\
\text { MVCs with Drivers having a Detectable Serum Ethanol } \\
\text { Concentration }\end{array}$ & $\begin{array}{l}\text { Number/Population } \\
\text { Exposed (Percent) }\end{array}$ \\
\hline & \\
Variable & $209 / 377(55.4)$ \\
\hline Passenger vehicle & $115 / 377(30.5)$ \\
Light truck or van & $143 / 324(44.1)$ \\
$\quad$ Driver wearing seatbelt in vehicle & $65 / 324(20.1)$ \\
Airbag deployed & $53 / 377(14.1)$ \\
Motorcycle & $50 / 53(94.3)$ \\
$\quad$ Driver wearing helmet on motorcycle & $161 / 377(42.7)$ \\
Driver requiring extrication & $292 / 377(77.5)$ \\
Single vehicle MVC & $134 / 377(35.5)$ \\
Vehicle rollover & $353 / 377(93.6)$ \\
Trauma team activation & $144 / 377(38.2)$ \\
Direct to trauma centre (LHSC) &
\end{tabular}

Table 3. Injury Profile by Abbreviated Injury Scale (AIS), Body Regions

\begin{tabular}{lc}
\hline AIS Body Region & Number (Percent) \\
\hline Head and neck & $187(49.6)$ \\
Face & $84(22.3)$ \\
Chest & $210(55.7)$ \\
Abdomen & $119(31.6)$ \\
Extremities and pelvis & $178(47.2)$ \\
External & $191(50.7)$
\end{tabular}

the amount of alcohol consumed by people who were planning to drive. Despite being geared toward young and novice drivers, the 2010 law had no significant effect on the proportion of severely injured drivers $\leq 21$ years, advocating for alternative strategies in this high-risk population.

The ethanol concentration drawn in hospital differs from the BAC at the time of the crash due to differences in sample matrix (i.e., blood vs. serum), but more importantly due to delays in sampling, which include time to activation of emergency medical services, extrication time, and transport time. Considering that ethanol declines by about $4.5 \mathrm{mmol} / \mathrm{L}$ per hour ${ }^{18}$ (legal BAC of $0.02 \%$ per hour), but varies depending on an individual's alcohol metabolism and other factors, we did not attempt to back-extrapolate hospital-drawn SEC to equivalent $\mathrm{BAC}$ at the time of the crash. It is recognized that, in most cases, the ethanol concentration will be substantially higher at the time of the collision.

There were several limitations to this study. The trauma registry only includes patients with an ISS $\geq 12$ and/or trauma team activation. Uninjured drivers, minor injuries, and deaths at the scene were not captured in this analysis. Most of the Canadian literature on legislative effectiveness focuses on mortality, which is a meaningful and easily measured endpoint. This study examines the severely injured population, which is an important group when one considers the lifetime of morbidity and assistance these patients may require from the health care and social systems. We could not control for external influences (e.g., MADD campaign) on a driver's decision to operate a motor vehicle while impaired in this design. Examination of the 2010 amendment was limited

\begin{tabular}{|c|c|c|c|}
\hline & $\begin{array}{c}\text { Proportion of } \\
\text { drinking drivers (\%) }\end{array}$ & $\begin{array}{l}\text { SEC of drinking } \\
\text { drivers only }(\mathrm{mmol} / \mathrm{L})\end{array}$ & $\begin{array}{c}\text { Proportion of } \\
\text { drinking drivers } \leq 21 \text { years (\%) }\end{array}$ \\
\hline & Estimate (SE) & Estimate (SE) & Estimate (SE) \\
\hline Baseline intercept & $23.63(2.40)^{*}$ & $31.21(0.72)^{*}$ & $27.06(5.09)^{*}$ \\
\hline Slope prior to OHTA law & $0.14(0.18)$ & $0.32(0.06)^{*}$ & $0.27(0.32)$ \\
\hline Level change at 2009 law & $-1.23(3.62)$ & $-2.21(1.79)$ & $\mathrm{n} / \mathrm{a}$ \\
\hline Slope after 2009 law & $-0.50(0.30)$ & $-0.51(0.09)^{*}$ & $\mathrm{n} / \mathrm{a}$ \\
\hline Level change at 2010 law & $\mathrm{n} / \mathrm{a}$ & $\mathrm{n} / \mathrm{a}$ & $-3.32(9.70)$ \\
\hline Slope after 2010 law & $\mathrm{n} / \mathrm{a}$ & $n / a$ & $-0.46(1.08)$ \\
\hline \multicolumn{4}{|c|}{$\begin{array}{l}\text { Note: All values are depicted in terms of units per quarter. } S E=\text { standard error. Baseline intercept }=\text { predicted value of the outcome at the star } \\
\text { of the study; } p \text { value signifies a difference from zero. Slope estimates }=\text { average predicted change in the outcome for each additional quarter } \\
p \text { value signifies the amount of change over time. Level estimates }=\text { immediate predicted change in the outcome at the initiation of the OHTA } \\
\text { law; } p \text { value signifies the amount of immediate change. }\end{array}$} \\
\hline
\end{tabular}




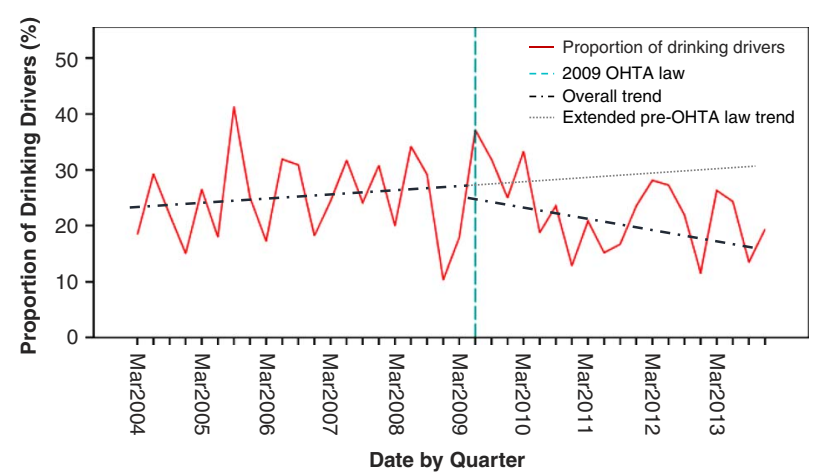

Figure 1. Average Proportion of Drinking Drivers from January 2004 to December 2013. The solid red line represents the average proportion of drivers with a detectable SEC by quarter (range of MVCs per quarter = 19-68). The dashed blue line represents the 2009 OHTA law. The dashed black line represents the average overall trend over time. The dotted grey line represents the extended pre-intervention trend predicted by the time series model.

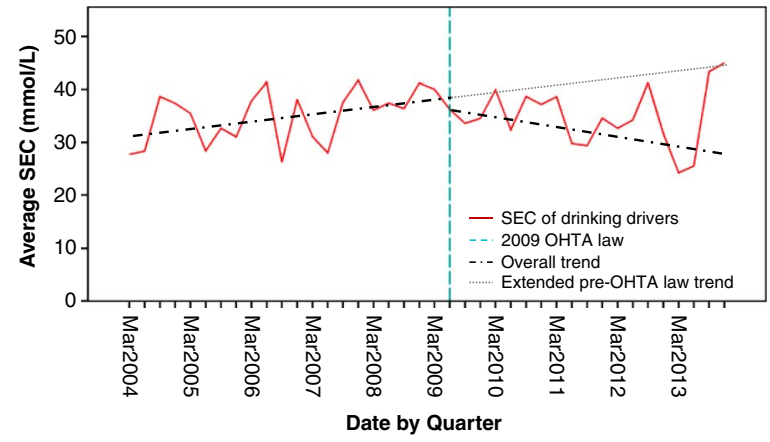

Figure 2. Average SEC ( $\mathrm{mmol} / \mathrm{L})$ of Drinking Drivers from January 2004 to December 2013. The solid red line represents the average SEC of drinking drivers by quarter (range of MVCs per quarter = 3-26). The dashed blue line represents the 2009 OHTA law. The solid black line represents the average long-term trend over time. The dotted grey line represents the pre-intervention trend predicted by the time series model.

by the small sample size of young drivers, which reduced the power of the time series analysis and may have limited our ability to detect a significant decline in drinking behaviour.

An ethanol concentration was routinely part of the trauma care set drawn at our hospital during the entire study period, but unfortunately it was not measured in 249 patients. These patients were evenly distributed over time in the study, but may have introduced some bias in the proportion of drivers who had a detectable SEC versus not. While we recognize that the time series analysis was limited by institutional changes over the 10 -year period, we are not aware of any changes to the

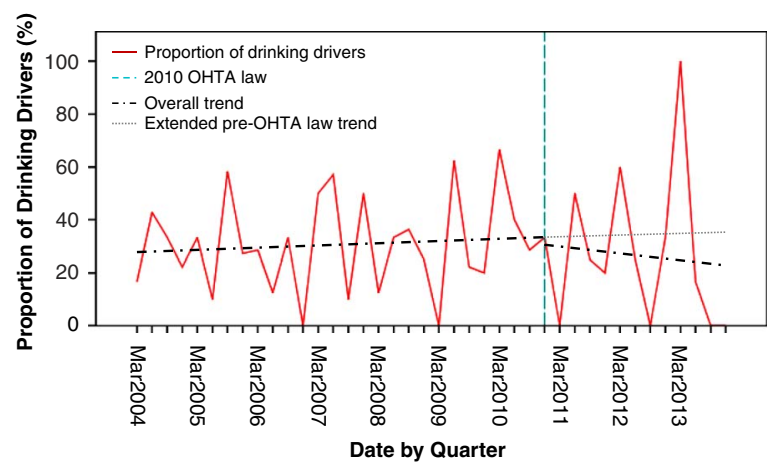

Figure 3. Average Proportion of Drinking Drivers $\leq 21$ Years of Age from January 2004 to December 2013. The solid red line represents the average proportion of drivers $\leq 21$ years of age with a detectable SEC by quarter (range of MVCs per quarter $=0-12$ ). The dashed blue line represents the 2010 OHTA law. The dashed black line represents the average overall trend over time. The dotted grey line represents the extended pre-intervention trend predicted by the time series model.

LHSC TTA criteria, trauma registry eligibility, or catchment area that would affect our results. Scene data such as seatbelt use and position in the vehicle were self-reported, but also corroborated by injury pattern and ambulance call reports before entry into the trauma registry. The version of the ISS used in the trauma registry was updated on April 1, 2012 to the 2005 version, before which the 1990 version was used. The 2005 version generally codes injuries lower, ${ }^{19}$ though there was no significant difference in the ISS between the two groups.

Future research should focus on traffic infractions and deaths at the scene to garner a more comprehensive assessment of the effects of the laws. We acknowledge that other forms of impairment, such as drug-impaired driving, texting while driving, and fatigued driving, are also at the forefront of road traffic safety and are other important areas for future research. At the same time, we hope the information from this study will remind clinicians, law enforcement officers, and policy-makers that alcoholimpaired driving is still a major threat to public safety that requires a multipronged approach of education, enforcement, engineering, and economic interventions. ${ }^{20}$

\section{CONCLUSIONS}

We conclude that there was no change in the proportion of drinking drivers after the 2009 OHTA amendment, but there was a significant decline in the average SEC of drinking drivers after changes to the law. There was no difference in the proportion of drinking drivers $\leq 21$ years 
after introduction of the 2010 amendment for young and novice drivers. The role of stricter laws, along with public health education and awareness campaigns, needs to continue to be explored to reduce the number of alcohol-related crashes and injury recidivism.

Acknowledgments: The authors gratefully thank Dr. Melanie Columbus for her feedback on the manuscript.

Competing Interests: None declared.

\section{REFERENCES}

1. Perreault S. Impaired driving in Canada. Stats Can; 2011. Available at: http://www.statcan.gc.ca/pub/85-002-x/ 2013001/article/11739-eng.htm.

2. Vanlaar W, Robertson R, Marcoux K, et al. Trends in alcohol-impaired driving in Canada. Accid Anal Prev 2012;48:297-302.

3. MADD Canada. Estimating the number and cost of impairment-related traffic crashes in Canada: 1999 to 2010; 2013. Available at: http://www.madd.ca/media/docs/ estimating_presence.pdf (accessed 29 July 2016).

4. Macdonald S, Zhao J, Martin G, et al. The impact of alcohol-related collisions of the partial decriminalization of impaired driving in British Columbia, Canada. Accid Anal Prev 2013;59:200-5.

5. Vingilis E, Blefgen $\mathrm{H}$, Lei $\mathrm{H}$, et al. An evaluation of the deterrent impact of Ontario's 12-hour license suspension law. Accid Anal Prev 1988;20(1):9-17.

6. Mann RE, Smart RG, Stoduto G, et al. The early effects of Ontario's administrative driver's license suspension law on driver fatalities with a BAC > $80 \mathrm{mg} \%$. Can 7 Public Health 2002;93(3):176-80.

7. Asbridge M, Mann RE, Smart RE, et al. The effects of Ontario's administrative driver's license suspension law on total driver fatalities: A multiple time series analysis. Drugs Educ Prev Polic 2009;16(2):140-51.

8. De Boni RB, Pechansky F, de Vasconcellos MT, et al. Have drivers at alcohol outlets changed their behavior after the new traffic law? Rev Bras Psiquiatr 2014;36(1): $11-5$.

9. Zivkovic V, Nikolic S, Lukic V, et al. The effects of a new traffic safety law in the Republic of Serbia on driving under the influence of alcohol. Accid Anal Prev 2013;53:161-5.

10. Purssell R, Brown D, Brubacher JR, et al. Proportion of injured drivers presenting to a tertiary care emergency department who engage in future impaired driving activities. Traffic Inj Prev 2010;11(1):35-42.

11. Fieldus $W$, Cain E. Impaired driving charges in injured impaired drivers requiring treatment in an emergency department. CFEM 2012;14(5):290-4.

12. Purssell RA, Yarema M, Wilson J, et al. Proportion of injured alcohol-impaired drivers subsequently convicted of an impaired driving criminal code offence in British Columbia. C7EM 2004;6(2):80-8.

13. Nagata T, Setoguchi S, Hemenway D, et al. Effectiveness of a law to reduce alcohol-impaired driving in Japan. Inj Prev 2008;14(1):19-23.

14. Mann RE, Macdonald S, Stoduto G, et al. The effects of introducing or lowering legal per se blood alcohol limits for driving: an international review. Accid Anal Prev 2001; 33(5):569-83.

15. Malta DC, Berna RTI, da Silva MMA, et al. Consumption of alcohol beverages, driving vehicles, a balance of dry law, Brazil 2007-2013. Rev Saude Publica 2014;48(4):692-6.

16. McMillan GP, Lapham S. Effectiveness of bans and laws in reducing traffic deaths. Am 7 Public Health 2006;96:1944-8.

17. Tabachnick BG, Fidell LS. Using multivariate statistics, Chapter 18: Time-series analysis. $5^{\text {th }}$ ed. Boston: Pearson Education; 2007.

18. Marx J, Hockberger R, Walls R. Rosen's Emergency Medicine - Concepts and Clinical Practice. $8^{\text {th }}$ ed. Chapter 185. Philadelphia: Elsevier; 2014.

19. Barnes J, Hassan A, Cuerden R, et al. Comparison of injury severity between AIS 2005 and AIS 1990 in a large injury database. Ann Adv Automot Med 2009;53:83-9.

20. Fildes J, Meredith JW, Kortbeek J, et al. Advanced Trauma Life Support for Doctors. $8^{\text {th }}$ ed. Chicago: American College of Surgeons; 2008. 